\title{
AN ANALYTICAL STUDY ON INDIFFERENCE MANAGEMENT IN EDUCATIONAL SYSTEM OF IRAN: REFLECTION ON EXPERT'S OPINIONS
}

\author{
Elham Abolfazli ${ }^{3}$, Reza Yousefi Saidabadi ${ }^{4}$, Vahid Fallah $^{5}$
}

\begin{abstract}
This study attempted to explore and analyse the indifference management trend in the Educational system of Iran. This objective was achieved through a qualitative approach and grounded theory. The population included all educational management professionals and experts who had at least two years of management experience. Twenty-four individuals were selected through purposive sampling based on theoretical data saturation. In order to collect research data, semi-structured interviews were adopted. Moreover, the results were evaluated through systematic analysis method based on open, core and selective coding. The findings suggested that the causal conditions affecting indifference management entail eight dimensions: job motivation, employee development, organisational culture, organisational climate, attitude and manager's performance, employee attitude, work environment and nature of work. Organisational culture, organisational climate and workplace conditions were the underlying factors of indifference management, while behaviour and performance of managers were mediating or confounding conditions, playing a dramatic role in indifference management.
\end{abstract}

KEY WORDS: indifference management, indifference in education system, indifference trend among employees

JEL: I21, J28

UDC: 005.32:331.101.3(55)

005.958.2

\footnotetext{
${ }^{3}$ Department of Educational Management, Sari Branch, Islamic Azad University, Sari, Iran,e-mail: Abolfazli_elham@yahoo.com

${ }^{4}$ Department of Educational Management, Sari Branch, Islamic Azad University, Sari, Iran,e-mail: ruosefi@yahoo.com

${ }^{5}$ Department of Lesson Planning, Sari Branch, Islamic Azad University, Sari, Iran, e-mail : vahidfallah20@yahoo.com
} 


\section{Introduction}

Nowadays, manpower is considered as the most strategic factor by researchers. Studies have shown that efficient and committed manpower will have desired results in performing tasks and providing services for the organisation. More importantly, due to technologic revolution occurred in recent decades, the role of human capital as an important organisational source has been highlighted (Bush, 2010; Daft, 2010; Bush, Middlewood, 2005).

In this regard, one of the main concerns of managers is to motivate employees as strategic assets of an organisation (Danaei Fard et al., 2010). Indifference and discouragement of employees to destiny and plans of organisation can be considered as an alarm for reduced organisational performance. In fact, the spirit of indifference in the behaviour of employees destroys their work and effort (Keefe, 2003).

Not paying attention to organisational regulations and the lack of accountability to clients (Byrd, 2008), being indifferent to the success or failure of organisation, lack of providing new solutions (Mirhosseini Zavareh, 1995), low self-esteem (Danaei Fard \& Eslami, 2010), carelessness in doing tasks, absence in work and not paying enough attention in performing duties (Moghimi, 2007) are among the signs of being indifferent.

Indifference gives rise to many negative consequences for both the individual and the organisation, including lack of motivation for working, low working efficiency, irresponsibility and loss of employment opportunities for indifferent individuals, which eventually leads to resignation or sense in insecurity (Abolalayee, 2015). Hence, organisational goals cannot be set based on employees who have been indifferent the organisation, because such indifference will leave an adverse impact on the motivation of employees (Leander, 2009). Each organisation on the road to success or even survival must create commitment inemployees and eradicate any sense of indifference. The Iranian Department of Education as the centre of gravity for training manpower similar to other organisations needs to achieve its lofty goals through enthusiastic, caring and committed employees, so as to remain viable and avoid unnecessary costs for recruiting new employees, taking more useful measures for its mission and tasks (Rezaeian, 2014). Indifference occurs when someone loses their hopes to achieve goals, striving to get over the source of desperation (Rezaeian, 2001, p. 99). What makes people give up and be indifferent is their profound and long discontent." (Eslami, 2008,p.23). Job alienation in knowledge-based employees such as school principals and teachers looks like a syndrome appearing as indifference, disgust, frustration, failure at school, negative attitudes towards education and work, indifference towards those activities, finding no identities in colleagues, students, negligence toward education and social communication, and cooperation with the management et al. Many scholars believe that individuals join organisations dynamically, but are deprived of innovation and growth as a result of inter-organisational relationships and wrong and selfish actions of executives arising from their illegitimacy. They ultimately become an inactive, isolated, indifferent, irresponsible and abnormal element. In such organisations, employees are given minimal control over their work environment. They encouraged remaining reliant subordinate, which is frequently observed in the public sector due to fundamental differences (Tavassoli, Ghadimi, 2001). False ideologies of "wide profitable table for all" and "the better you work, worse the results you face" reflect the profound indifference in the public and semi-public sectors. Managers often associate the problem of human resources with symptoms such as lack of creativity and innovation in work, low productivity, lack of motivation at work and turnover. Therefore, one of the factors 
leading to non-productivity of human resources can be found within the employee indifference toward the organisation. Organisational indifference is a destructive factor latently degrading any organisation. Indifference in organisation represents a problem regarding which managers must take seriously the dangers of corporate indifference, employee turnover, absenteeism, negligence, lack of attachment and pride in the organisation, low motivation and finally organisation left by employees (especially those who are highly specialised and function a key asset) will have excessive costs for training, empowerment and employment. The above problems can be controlled and be regarded as capabilities for organisations that have recognised their sensitivity (Mehrabian et al., 2011). Finding out what items and qualities in others cause indifference leads to self-awareness, thereby inhibiting the indifference. The literature review suggested that despite a broad range of theoretical and practical efforts to avoid indifference and create employee motivation, little investigation has been specifically focusing on the factors contributing to organisational indifference management in the Educational system of Iran, leaving the issue shrouded in mystery. The overview of previous papers concerning the factors either directly or indirectly contributing to organizational indifference management obtained three structural, motivational and managerial factors. Regarding the factors contributing to indifference, very few studies have been conducted, focusing mainly on two or three variables. Organizational culture, motivational factors, environmental conditions, employee empowerment and leadership style are among the most important factors in improving the productivity of human resources (Mehrabian et al., 2011). Justice plays an important role in the health status of employees and the effectiveness of human resources in an organization (Elovaino et al., 2005, quoted by Jahanian and Ghodsi, 2014). The most important factors in preservation and survival of the organization in the long term lies in justice (Masterson, 2002). Sense of injustice would cause feelings of worthlessness and low self-esteem, thus distracting the individuals from their tasks (Nair,Vohra, 2010). Following the increase in the intellectual abilities of employees, new training methods, non-admonition, embracing new ideas, a sharp decline in punishment, strengthening employee satisfaction, division of power between employees etc. Therefore, employees will enjoy their work and are constantly on the dynamics, where such an organization will never encounter indifference.

Manpower is the primary capital, competitive advantage and success factor of the organization. Thus, lack of employees with good working and moral characteristics will undermine the success of the organization (Roy, Lyenger, 2005). As a result, the abilities such as decision-making, innovation and creativity, monitoring over one's performance, accountability (Dimitriades, 2011) and ideal traits such as dedication, altruism, generosity, work ethic etc. in employees has been known as a unique competitive advantage that leads to good behavior on the part of employees and ultimately the success of the organization. Empowerment of employees is one of these approaches adopted in recent decades leading to many positive developments in the implementation of activities. This study sought to explain and analyze the process of indifference management in the Educational system of Iran with a particular focus on Ardebil Department of Education 


\section{Research objectives}

\section{General objective}

Analyzing the indifference management in Educational system of Iran

\section{Specific objectives}

- Analyzing the dimensions and components of indifference management in Educational system of Iran

- Analyzing the causal conditions of indifference management in Educational system of Iran

- Analyzing the underlying conditions of indifference management in Educational system of Iran

- Analyzing the confounding conditions of indifference management in Educational system of Iran

\section{Research questions}

- What are the dimensions and components of indifference management in Educational system of Iran?

- What are the causal conditions of indifference management in Educational system of Iran?

- What are the underlying conditions of indifference management in Educational system of Iran?

- What are the confounding conditions of indifference management in Educational system of Iran?

\section{Methodology}

The philosophical foundation behind this study involves a quest of knowledge through the opinions of specialist participants (subject matter experts). In fact, the philosophical foundation lies in interpretative epistemology that reflects research that lead to qualitative approach. Because the views and experiences of the participants can be understood through immediate limitation under a predetermined framework realized through a qualitative approach. In addition, evidence suggests that qualitative research can provide a proper approach to exploration of newly emerging data (Creswell J. w., 2012; Creswell, 2009; Hatch, 2002; Donoghue,Punch, 2003; Marshall,Rossman, 1999; Maxwell, 1996).

This study involved the grounded theory, since it can function both as an instrument for theorization and a set of techniques for qualitative research (Biabangard, 2013). The inferring basis is inductive method, where the theory was developed through an inductive procedure involving a study on the phenomenon. In other words, the theory must be proved, explored 
and completed through certain systematic methods (Strauss,Corbin, 2014). Among qualitative and interpretative methods, the grounded theory has unique advantages for researchers, because it has a high capacity to interpret complex phenomena giving more elbow room to the researcher for an in-depth examination of concepts (Mohammadpour, 2013). Grounded theory involves a field study of phenomena describing the natural locations such as hospitals, classrooms and organizations. Its main objective is an in-depth evaluation of actions, behaviors, beliefs and attitudes of individuals and groups is the same way as occurred in real life, so as to clarify the social processes in that particular field (Adib Hajbagheri, 2006). Application of this method has been recommended in situations where there is very little understanding of a phenomenon or when the existing theories entail inadequate explanation of the phenomenon (Parker,Myrick, 2011 quoted by Mohammadpour, 2013). Given that the subject of this study involved organizational indifference management so far neglected in Iranian training centers and rarely investigated, there are no theories proposed, thus requiring the grounded theory.

The population consisted of education professors at universities and educational professionals specialized in educational administration who had at least two years of management experience. Moreover, a total of 20 key experts were selected through purposive sampling based on data saturation. However, the interviews continued to 24 subjects, so as to ensure higher level of confidence. Interviews were conducted upon prior authorization. Before the interview, the subject and purpose of the study were explained to the interviewees who were then assured of information confidentiality. The theoretical data saturation refers to a point where sampling is stopped as there are no newer comments and opinions proposed. In theoretical sampling, only individuals were selected with adequate technical views and experiences in relation to the issues.

In order to collect data, semi-structured interviews were developed. In this procedure, the interviewee was given a general open-ended question concerning the subject of research, leaving their opinions without limitation in terms of the conceptual framework. The reason behind adoption of such type of interview was that the researcher would be able to explore limitlessly the comments, world views and experiences of participants, constituting the philosophical foundation of any qualitative research. It is worth noting that during the interviews and upon the permission of participants, a tape recorder was used to record data, which were then converted into a transcript. The data were validated through the following measures: 1) reviewing and analyzing the categories obtained by the sample group of experts and specialists, i.e. member checking (Maxwell, 1996; Creswell, 2012); 2) participant feedback based leaving comments and views on during the interview, in order to modify items wrongly understood by the researcher, and 3) compliance and homogeneity of findings or triangulation where the researcher can employ the partnership of another researchers for encoding and reviewing the categories, which took place as a group through validation.

Finally, the deductive grounded theory was adopted to analyse the findings based on open coding, core coding and selective coding. In open coding, data are collected from the participants, and are then coded regardless of any particular theoretical basis. In the next step, which is core coding, coded data are summarized and reduced until a broader range of categories and classes is achieved and there are more detailed codes (Creswell, 2012). In selective coding, the core phenomenon of research is examined in relation to other categories (Creswell, 2013). It is worth noting that in open coding phase, the recorded interviews after implementation are line by line reviewed, conceptualized and categorized depending on similarity, conceptual relations and common characteristics. The number of obtained codes was specified through primary conceptual propositions. In the next step extracting the categories from open codes and developing the core codes, a total of 21 concepts and then 8 
major categories were obtained. These categories were labelled as motivational work, employee development, organizational culture, organizational climate, attitude and performance of managers, employee attitude, work environment and the nature of work.

\section{Findings}

Considering the evident relationship between the experts and subject matter, the subjects were requested to participate in the study and respond to the semi-structured interviews. What follows is the results obtained from expert interviews. In order to better organize the findings, each finding was examined in relation to the research questions.

What are the dimensions and components of indifference management in Educational system of Iran?

The findings obtained from this study showed that indifference management in Educational system of Iran entails 8 major dimensions; the underlying component of each has been displayed in Table (1).

Table 1: Eight categories obtained from coding

\begin{tabular}{|c|c|c|c|}
\hline Concept & Category & Concept & Category \\
\hline Job salaries and benefits & \multirow{3}{*}{ Motivational work } & Teamwork & \multirow{3}{*}{$\begin{array}{l}\text { Organizational } \\
\text { climate }\end{array}$} \\
\hline $\begin{array}{l}\text { Assessment and } \\
\text { promotion }\end{array}$ & & Organizational intimacy & \\
\hline Physical work conditions & & $\begin{array}{l}\text { Importance of creativity } \\
\text { and innovation }\end{array}$ & \\
\hline Specific objectives & \multirow{2}{*}{$\begin{array}{l}\text { Organizational } \\
\text { culture }\end{array}$} & $\begin{array}{l}\text { Core competencies } \\
\text { through training }\end{array}$ & \multirow{2}{*}{$\begin{array}{l}\text { Employee } \\
\text { development }\end{array}$} \\
\hline $\begin{array}{c}\text { Commitment to the } \\
\text { organization }\end{array}$ & & $\begin{array}{l}\text { Job-learning } \\
\text { development }\end{array}$ & \\
\hline $\begin{array}{c}\text { Attention to employee } \\
\text { performance }\end{array}$ & \multirow{3}{*}{$\begin{array}{l}\text { Behavior and } \\
\text { performance of } \\
\text { managers }\end{array}$} & Organizational trust & \multirow{3}{*}{ Employee attitude } \\
\hline Providing solutions & & Organizational justice & \\
\hline Organizational justice & & Organizational support & \\
\hline Lack of formalization & \multirow{3}{*}{$\begin{array}{l}\text { Organization } \\
\text { structure }\end{array}$} & Designed job description & \multirow{3}{*}{ Nature of work } \\
\hline Delegation of authority & & Job fitting with the & \\
\hline Decentralization & & expertise of employees & \\
\hline
\end{tabular}

\section{Core coding}

In core coding, one of the components of open coding is selected as the primary concept or phenomenon (the process under study) and is then examined in the core of process, while interconnecting other categories (Strauss, Corbin, 2014). In core coding, it is essential to examine four categories of phenomena involved in data analysis aiming to formulate a theory based on research questions, covering the causal conditions, action and interaction conditions, underlying conditions, confounding conditions and outcomes (Mohammadpur, 2013).

\section{What are the causal conditions of indifference management in Educational system of Iran?}

These categories resulting from causal conditions or preceding circumstances refer to events or incidents leading to occurrence or expansion of a particular phenomenon (Strauss,Corbin, 2014). 
The results of content analysis for the responses provided by interviewees to items such as how do you find the organizational indifference management? And factors contributing to the organizational indifference management indicated there are three main categories concerning causal conditions to create the phenomenon under study, where the open codes have been displayed in Table 2 .

Table 2: Open codes, categories concerning causal conditions

\begin{tabular}{|c|c|c|c|}
\hline Open codes & $\begin{array}{c}\begin{array}{c}\text { Sub- } \\
\text { categories }\end{array} \\
\end{array}$ & Categories & \\
\hline $\begin{array}{l}\text { Proportion of salaries and benefits with } \\
\text { assigned responsibilities } \\
\text { Equitable salaries and benefits compared } \\
\text { with colleagues } \\
\text { Adequacy of benefits and amenities }\end{array}$ & $\begin{array}{l}\text { Job salaries } \\
\text { and benefits }\end{array}$ & \multirow{3}{*}{ 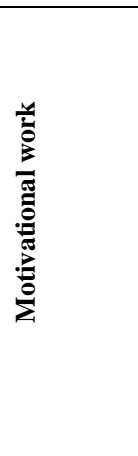 } & 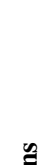 \\
\hline $\begin{array}{c}\text { Vitality in the workplace } \\
\text { Accessibility to essential equipment and } \\
\text { facilities } \\
\text { Sufficient space for carrying out tasks }\end{array}$ & $\begin{array}{l}\text { Physical work } \\
\text { conditions }\end{array}$ & & 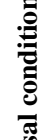 \\
\hline $\begin{array}{l}\text { Desirability of reward and punishment } \\
\text { system } \\
\text { Job-path development } \\
\text { Employee assessment based on their } \\
\text { actual performance }\end{array}$ & $\begin{array}{l}\text { Assessment } \\
\text { and promotion }\end{array}$ & & ฮે \\
\hline $\begin{array}{c}\text { - Proportional powers and responsibilities } \\
\text { - Appropriate work allocation } \\
\text { — Proportion of workload with dedicated } \\
\text { deadline }\end{array}$ & $\begin{array}{c}\text { Designed job } \\
\text { description }\end{array}$ & \multirow{2}{*}{ 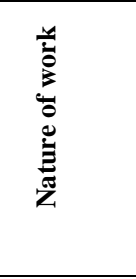 } & \\
\hline $\begin{array}{l}\text { Job fitting with the expertise of individual } \\
\text { Job fitting with previous expertise } \\
\text { Proportion with personality traits }\end{array}$ & $\begin{array}{l}\text { Job fitting } \\
\text { with the } \\
\text { expertise of } \\
\text { individual } \\
\end{array}$ & & \\
\hline $\begin{array}{l}\text { - Sympathy, empathy and cooperation } \\
\text { between employees } \\
\text { — Promoting cooperation level based on trust } \\
\text { - Trust in behavior, words and performance } \\
\text { of the manager }\end{array}$ & $\begin{array}{l}\text { Trust in the } \\
\text { organization }\end{array}$ & \multirow{3}{*}{ 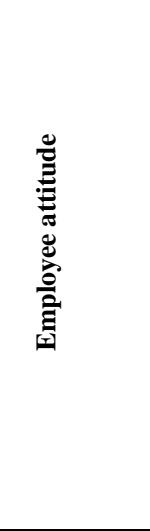 } & \\
\hline $\begin{array}{c}\text { - Position of each individual on the basis of } \\
\text { merit } \\
\text { - Exercising justice in dealing with } \\
\text { employees } \\
\text { - Meritocracy }\end{array}$ & $\begin{array}{l}\text { Justice in the } \\
\text { organization }\end{array}$ & & \\
\hline $\begin{array}{c}\text { - Attention to the well-being of employees } \\
\text { - Attention to statements and problems of } \\
\text { employees } \\
\text { - Assistance when employees encounter } \\
\text { problems }\end{array}$ & $\begin{array}{l}\text { Organizational } \\
\text { support }\end{array}$ & & \\
\hline
\end{tabular}

In this study, causal conditions referred to conditions entailing the main factor contributing to indifference management in Educational system of Iran. These conditions throughout the analyses were based on motivational work, nature of work and employee attitude depending on the expert's opinions. All experts agreed that the Department of Education does not pay serious attention to solving the economic problems of employees. Moreover, the full reliance of the Department of Education on the government non-profitable nature of the organization has added to the burden of issues. Job satisfaction is realized through the trade-offs in the organization, while it will curtail as long as the employee needs are not fulfilled. If real opportunities for advancement within the organization are not made 
available to employees and evaluation is not based on facts, there will be escalated indifference among employees. Furthermore, the appropriateness of the powers and responsibilities and division of tasks, physical conditions of work, access to equipment and facilities necessary to carry out the tasks are among important factors contributing to indifference of individuals towards work, colleague, organization, clients and the manager. Moreover, experts emphasized that perception of employees toward the organization is one of the most important factors contributing to indifference management. Support from organization for its employees can be helpful to problems, and the fairness perceived by employees play a key motivational role in job and indifference management.

\section{What are the underlying conditions of indifference management in Educational system of Iran?}

The underlying conditions represented specific situations affecting the strategy (Strauss,Corbin, 2014). In this study, three categories of organizational culture, work environment and organizational climate were effective in strategies as displayed in Table 3.

Table 3: Open codes, categories concerning underlying conditions

\begin{tabular}{|c|c|c|c|}
\hline "Open codes & Sub-categories & Categories & \multirow{9}{*}{ 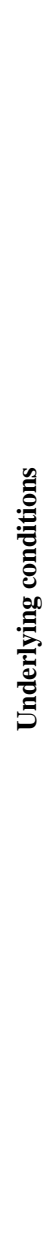 } \\
\hline $\begin{array}{l}\text { Specificity of organizational goals } \\
\text { Identified prospects by the manager } \\
\text { Motivational goals and objectives }\end{array}$ & Specific objectives & \multirow{2}{*}{ 栉 } & \\
\hline $\begin{array}{l}\text { Job considered as a value } \\
\text { Embracing changes and new working practices } \\
\text { Employee involvement in the activities of the } \\
\text { organization }\end{array}$ & $\begin{array}{l}\text { Commitment to the } \\
\text { organization }\end{array}$ & & \\
\hline $\begin{array}{l}\text { Formation of work-groups } \\
\text { Adoption of expert's opinions } \\
\text { Integrity of tasks through collaboration } \\
\text { A spirit of partnership }\end{array}$ & Teamwork & \multirow{3}{*}{ 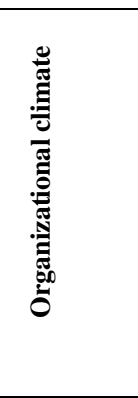 } & \\
\hline $\begin{array}{l}\text { Friendly interactions } \\
\text { Socialization outside the workplace } \\
\text { Interacting with respect } \\
\text { Manager intimacy with employees }\end{array}$ & Intimacy & & \\
\hline $\begin{array}{l}\text { Encouraging employees toward being creative } \\
\text { and innovative } \\
\text { Raising ideas without any fear } \\
\text { Fostering creativity and innovation }\end{array}$ & Creativity & & \\
\hline $\begin{array}{l}\text { Employees making decisions without superiors } \\
\text { involvement } \\
\text { Informal communication channels } \\
\text { Overlooking certain guidelines }\end{array}$ & Lack of formalization & \multirow{3}{*}{ 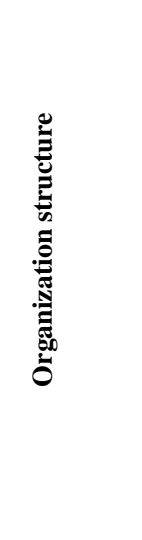 } & \\
\hline $\begin{array}{l}\text { Giving each person responsibility depending on } \\
\text { their capacity } \\
\text { Employee involvement in the activities of the } \\
\text { organization } \\
\text { Objectives outlined by the manager and } \\
\text { implemented by employees }\end{array}$ & Delegation of authority & & \\
\hline $\begin{array}{l}\text { Lack of formalization } \\
\text { Delegation of authority } \\
\text { Decentralization }\end{array}$ & Organization structure & & \\
\hline
\end{tabular}


In identifying and examining the behavior and performance of members at an organization, awareness of organizational culture and climate are fundamental steps. Because culture creates a collective identity helping the members of the group in coordination and compliance with policies, missions and goals of the organization (Hariudin Mohd, Borhandden, 2012). In formulating a strategy, it is crucial to identify organizational culture (Sargazi,Mohammadyari, 2014). Organizational culture plays an undeniable role in the success of business changes (Raouf, 2013). In this study, clear objectives were labeled commitment to work and motivation as culture, where the commitment and motivation together represent the work culture, which is a subset of the organizational culture. In order to understand the organization and the behavior/performance of employees, it is essential to understand the culture, since it simply facilitates enforcement of changes and sustains the new organizational orientation (Alvani, 2004). Hence, if managers are seeking to increase productivity and organizational performance, they should concentrate on the constituent factors of culture. When employees internalize the organizational values, and find their jobs so significant and motivating with feelings of solidarity with their colleagues, there will be greater commitment to the organization. Another underlying category is organizational climate. Indifference is developed and curtailed based on whether or not there is emotional intimacy in the organizational climate, creativity and innovation are encouraged and teamwork is valued.

What are the confounding conditions of indifference management in Educational system of Iran?

The confounding conditions are general and wide-range conditions affecting actions/interactions mechanism (Strauss, Corbin, 214). Based on interviews with experts, two categories of behavior and performance of managers, employee development were labeled as confounding conditions.

Table 4:Open codes, categories concerning confounding conditions

\begin{tabular}{|c|c|c|c|}
\hline Open codes & $\begin{array}{c}\text { Sub- } \\
\text { categories }\end{array}$ & Categories & \multirow{6}{*}{$\begin{array}{l}\tilde{0} \\
: 0 \\
: 0 \\
0 \\
0 \\
0 \\
0 \\
0 \\
0 \\
0 \\
0 \\
0\end{array}$} \\
\hline $\begin{array}{c}\text { Developing the employee capabilities } \\
\text { Providing a variety of methods and solutions } \\
\text { to solve job problems } \\
\text { Providing strategies to achieve objectives }\end{array}$ & $\begin{array}{l}\text { Providing } \\
\text { solutions }\end{array}$ & \multirow{3}{*}{ 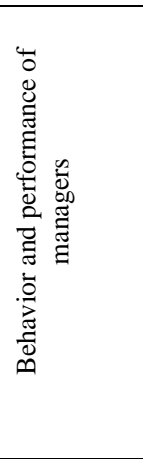 } & \\
\hline $\begin{array}{l}\text { Aware of manager about the influence of their } \\
\text { words on employee performance } \\
\text { Awareness of the manager about their } \\
\text { strengths and weaknesses } \\
\text { Embracing criticisms openly }\end{array}$ & $\begin{array}{c}\text { Self- } \\
\text { consciousness }\end{array}$ & & \\
\hline $\begin{array}{c}\text { Giving feedback on jobs } \\
\text { Continuous evaluation of employees } \\
\text { The emphasis of the manager on the role of } \\
\text { employees in improving organizational } \\
\text { performance }\end{array}$ & $\begin{array}{l}\text { Attention to } \\
\text { employee } \\
\text { performance }\end{array}$ & & \\
\hline $\begin{array}{c}\text { The ability to influence others } \\
\text { Effectiveness } \\
\text { Usefulness }\end{array}$ & $\begin{array}{l}\text { Core } \\
\text { competencies } \\
\text { through } \\
\text { training }\end{array}$ & \multirow{2}{*}{ 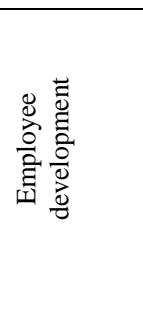 } & \\
\hline $\begin{array}{l}\text { Learning on the job } \\
\text { Practical training } \\
\text { Continuous development of skills and } \\
\text { competencies of individuals } \\
\text { The possibility of obtaining new work } \\
\text { experience }\end{array}$ & $\begin{array}{l}\text { Job-learning } \\
\text { development }\end{array}$ & & \\
\hline
\end{tabular}


By providing solutions and transparent relationships with employees and focus on their performance, managers can become competent leaders for the organization. Dehghan et al. (2012) argued that the primary role of any leader is to unite individuals around key values of the organization. Educational leaders must create an organizational climate full of confidence, mutual respect, and collaboration to solve problems (Shahmansouri,Sokutarani, 2015). Employee experience is achieved through empowerment, dramatically affecting job promotion and evolution, raising the sense of being useful in employees.

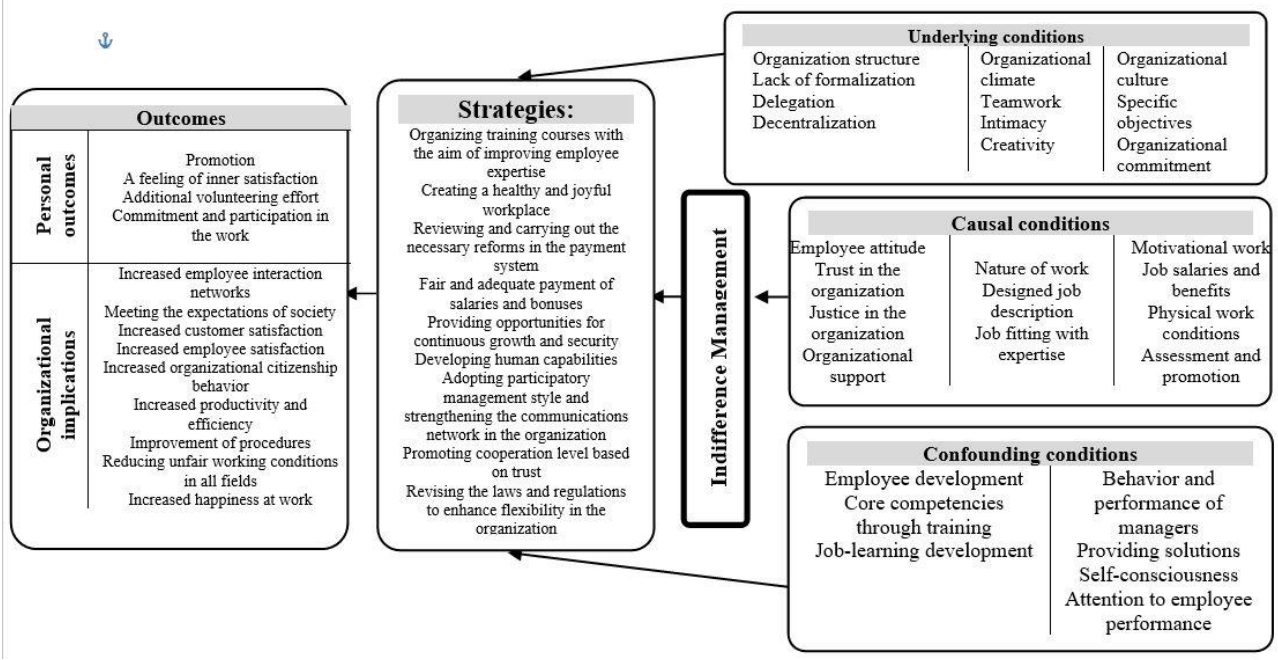

Figure 1:Ilustrate the research paradigm according to the items inserted into core coding

\section{Discussion and conclusions}

Since exploration within the subjective world and experiences for extraction of opinions require a qualitative research method, the grounded theory was employed since it was consistent with the objective and main question of this research (Biabangard, 2013). In order to collect data, semi-structured interviews were employed. Finally, after reaching theoretical saturation, interviews were administered with 24 members of the Education system, university professors and professionals in the field of education management who had at least 2 years of management experience in Educational system of Iran. The collected data were compared and then organized through open coding, core coding and selective coding in the form of eight categories and 21 concepts. The results of analysis on the collected data were developed into a grounded theory titled the Theory of Indifference Management in Education System. It seeks to explore the process of organizational indifference management in the Educational system of Iran.

\section{Factors contributing to indifference management}

In this study, commitment to the organization and specific goals was labeled as an organizational culture. In order to understand the organization, the behavior and performance of employees, it is crucial to evaluate culture. When employees internalize the organizational 
values, find their jobs motivating and meaningful with a feeling of solidarity with their colleagues, there will be greater commitment to the organization. Healthy and positive work culture in a society and specifically in an organization creates a kind of commitment which is far more valuable than personal interests of employees (Faraji, 2014). Moreover, work motivation, factors, conditions, benefits and situations triggering and directing individual behavior are desirably linked with employment opportunities, which is consistent with opinions of Jalali (2014), Amiri (2013) and Latifian et al. (2013).

In this study, satisfaction with evaluation and promotion, wages and benefits and the physical conditions of work were labeled as motivational aspects of work, which was consistent with opinions of Golparvar et al. (2010) and Seyed Javadin (2015) who found that employee satisfaction entail cognitive emotional reaction in the form of attitude toward work, and Moeedfar and Zahani (2015) who believed unsatisfied needs and job dignity are correlated with job satisfaction and Moghimi (2007) who divided job satisfaction into salary, promotions, working conditions and nature of work. In this regard, Brodaty and Burns (2012) similarly argued that job dissatisfaction leads to indifference. Hence, the more needs are fulfilled and secured, there will be higher satisfaction, thus enhancing motivation and commitment as cultural dimensions of working. Moayedi (2013) achieved a significant relationship between job characteristics and organizational indifference. Job-learning development and creation of competencies through training was labeled as employee development. The results of this study were consistent with those obtained by Isakhani et al. (2013) who argued that growth and learning opportunities were among career resources effective in belonging to the organization, Dehghan et al. (2012) who found that there is a relationship between education/empowerment and job satisfaction and organizational commitment, and Balker (2015) who believed that job satisfaction was realized through empowerment and Ehrheart (2014) who found that employee empowerment led to a prospect of overcoming indifference and attaining job satisfaction. Concepts of attention to employee performance, providing solutions and self-consciousness of manager were labeled as behavior and performance of employees. Based on extensive research of the world's largest polling firm, Gallup, only $10 \%$ of people are talented in management. Therefore, success in business administration and management requires a variety of talents and skills, integration of which rarely happens in one individual. According to Gallup research, these five personality talents can make individuals great managers: motivation, determination, decision-making, accountability and building relations (Bastanipour Moghaddam, 2015). According to Gardner et al., managers tend to foster self-awareness and ultimately positive self-development consistent with the label in this study. This type leadership develops when the leader expands the interests of employees, provides the essential awareness and acceptance to carry out their mission and propel employees towards a direction beyond their interests and priorities of collective interests over individual interests (Stone et al., 2004). Therefore, leadership principles involve development of self and followers, which can be facilitated by empowered employees. In addition, the concepts of importance of creativity and innovation, organizational intimacy and teamwork were labeled organizational climate, which was consistent with opinions of Litwin and Stringer (1968) who found that organizational climate covers perceptions of individual about the type of organization where they works and their sense of belonging in terms of responsibility, structure, reward, warmth, support, identity, risk-taking, conflict and standards (Karimi et al., 2010). According to Hoy and Miskel (2007), it should be noted that organizational climate is a broader term referring to the perception of employees about the general workplace conditions. 


\section{Strategic categories}

Strategies in the grounded theory provide solutions to deal with the phenomenon under study. In other words, strategies serve to manage how to treat, accomplish and respond to the phenomenon (Mohammadi, 2014). This study proposed four strategies, including:

\section{Establishment of empowerment and development courses}

Empowerment functions as a useful means of improving the quality of human resources and increasing organizational effectiveness. In order to achieve business success in today's ever-changing environment, organizations require the knowledge, opinions, energy and creativity of all employees, ranging from frontline employees to top-ranking managers. To accomplish this, organizations take measure by enabling managers to encourage employees to take the initiative, honoring the collective interest of the organization with minimum supervision and duty as the owner of the organization. The purpose of empowerment is to maximize the adoption of employee capabilities in attaining organizational goals. In addition to the positive impact on organizational, employee empowerment can leave positive effects on employees. Moreover, empowerment changes employee attitude and enhances job satisfaction. Job independence, elbow room and freedom in decision-making are among additional outcomes of such attitude. However, the behavioral effects can increase the confidence of employees, increase the power of compliance, and accelerate responsiveness to customers and so on. When the job duties of employees are not fitting with their skills and interests, they are forced to carry out their duties. On the other hand, it becomes difficult for employees to be creative. Thus, employee empowering opens up a window toward promotion and success. Empowerment affects employee behavior (high performance or indifference), given that employee empowerment can provide more opportunities for freedom, improve employees' skills and knowledge, so they attain job satisfaction, adhere to organizational goals and actions will be commensurate with the goals of the organization.

\section{Attention to the salaries and benefits of employees and revision in laws and regulations}

Reward systems are important tools that managers can use to propel employee motivation. The reward system comprises all elements of an organization such as individuals, processes, rules and decision-making activities, paid as allocation of compensatory payments and benefits to employees in exchange for cooperation (Morhead, Griffin, 2006). Rewards must meet the basic needs of employees, entail the appropriate reward policies and leave dramatic effects on encouraging employees to do the tasks. Moreover, a revision in certain laws and regulations by flexible organizational practices can stimulate more motivation in employees.

\section{Attention to job satisfaction}

Job satisfaction indicates to what extent a person loves their work and how assesses the job and whether or not there is positive feeling. The assessment refers to perceived job characteristics, job feelings and work environment (Gholipour, 2009). Job satisfaction will increase individual productivity, commitment to the organization, guarantees physical and mental health, boosts individual spirit, happy life and job skills quickly trained.

\section{Outcomes of indifference}

They are divided into two categories of personal and organizational. The organizational outcomes increase employee engagement network, meet the expectations of society, increase customer satisfaction, increased employee satisfaction, increase organizational citizenship 
behavior, increase productivity and efficiency, improve how things are done, lower unfair labor conditions and increased vitality in all fields of work. Job characteristics, pre-service and inservice training, fair compensation and job satisfaction dramatically curtail the fatal disease of indifference within the organization. Hence, the human resource management systems entail all these components, leaving an impact on job satisfaction (Yazdani et al., 2015). The personal outcomes of indifference are promotion, a sense of inner satisfaction, and increased volunteer effort, commitment and participation in the tasks. When employees feel that the organization is loyal to them, there will be greater job security, while the benefits and salaries are protected by the organization, with more motivation and enthusiasm, concentrate on their tasks without any marginal issues and job insecurity, which can in turn enhance productivity of human resources. In addition, employees supported by organizations tend to be loyal to the organization in return. They will be less likely to take occupational risks and leave the organization, because they feel faith and commitment to the organization and its objectives (Moeedfar, Zahani, 2005). Therefore, the elimination of indifference among employees of an organization, motivation and high quality, cooperation, empathy and sympathy are all meaningful. The commitment of individuals lead to a joyful environment and changes are welcome. Nobody is seeking higher salaries than accepted standards and health of employees is sustained.

\section{Recommendations}

- According to the results suggesting that the behaviour of managers as well as employee development are confounding factors of indifference, it is recommended that subsequent research focus on pathology of these two categories in the education system.

- Given that the organizational climate and working conditions were underlying factors of indifference, it is suggested that further research can adopt ethnographic methods to analyse organizational climate in the education system.

- Given that organizational culture played an important role in indifference, it is suggested that further research be conducted to analyse its effects.

\section{Limitations}

- Conservative interviewees and avoidance of talking about controversial issues

- Exclusion of several interviewees by their respective General Departments

\section{Acknowledgment}

This article is an excerpt from Elham Abolfazli Doctoral thesis the Ph.D. candidate in Educational Management at Islamic Azad University of Sari which has been conducted during the years 2014-16. 


\section{References}

[1] Abolalayee, B. (2015). How to have motivated and love working employees. Tehran: Industrial Management Organization.

[2] Adib Hajbagheri, M. (2006). Methods of qualitative research. Tehran: Boshra

[3] Alvani, M. (2004). General Management: Ney Publication.

[4] Amiri, Y. (2013). Identify and prioritize the factors influencing organizational indifference from the perspective of women and men using fuzzy analytic hierarchy process. The $2^{\text {nd }}$ National Conference of Modern Management Sciences . Gorgan, Iran.

[5] Bastanipour Moghaddam, M. (2015). Competent Managers and Organizational Change. Hamshahri Newspaper: electronics version.

[6] Biabangard, I.(2013). Research Methods in Psychology and Educational Sciences (Volume II). Tehran:Doran

[7] Brodaty, H.,Burns, K. (2012). Behaviour management A Guide ti good practice. Managing Behavioural and psychological symptoms of Dementia. Dementia Behaviour management advisory service. Online at dbmas.Org. au.

[8] Bush, T., Middlewood, D. (2005). Leading and managing people in education. London, New Delhi: Sage publication.

[9] Bush, T. (2010). Theories of educational management and leadership (third edition). London, New Delhi: Sage publication.

[10] Byrd, David(2008). The Tripping Point in Leadership: Overcoming Organizational Indifference. Texas, slight Edge Publishing.

[11] Creswell J. W. (2012). Educational research: planning, conducting and evaluating quantitative and qualitative research (Fourth edition). Pearson. Boston.

[12] Creswell, J. W. (2013). Research design: qualitative, quantitative and mixed method approaches (third edition).Sage publications London: New Delhi.

[13] Daft, R, L. (2010). Organization theory and design (tenth edition). America: southwestern cengage learning.

[14] Danaee Fard, H.,Eslami, A. (2010). Discovering Theory of Organizational Indifference: A Grounded Theory Strategy. European of Seientifile. (C) EuroJournals Publishing, Inc,40(3), 450-460.

[15] Dimitriades, Z.S. (2005). Employee empowerment in the Geerk context: A constructive replication. Paper presented at the 8th Bi-annual conferece of the International Society for the study of Work and organizational values (ISSWOV), Warsaw, Poland.

[16] Donoghue, t.o.,Punch, K. (2003).Qualitative educational research in action.Simultaneously. Published in the USA and Canada: RoutledgeFalmer..

[17] Danaei Fard, H., Hassanzadeh, A.,Salariyeh, N.(2010). Designing a measure to measure organizational indifference: a combination study. Journal of Strategic Management of Thought, 4 (2): 79-99.

[18] Dehghan, N.; Omranifar, A.; Hosseini, M. R.,Fathi, S. (2012).The relationship between organizational justice and job satisfaction. Military Management Journal, 12 (46): 102-65. 
[19] Dehghan, N.; Fathi, S.; Garjami, S.,Valivand, H.(2012). The impact of managers commitments on organizational commitment, job satisfaction and employee performance. Journal of Management Studies (recovery and development), 22 (67): 128-97

[20] Eslami, A. (2008). Institutional indifference: Strategy of Grounded Theory. Master thesis, Adviser Hassan Danayeefard, Department of Allameh Tabatabai University, College of Graduate Studies.

[21] Faraji, J.(2014). The role of work and production culture in creating economic saga. Monthly journal of Labor and Society, 176: 70-64.

[22] Gholipour, A. Pourezzat, A. A.; Hazrati, M. (2009). The effect of servant leadership on organizational trust and empowerment in government agencies. Public Administration Journal. 1 (2): 103-188.

[23] Golparvar, M.; Chavadiyan, Z.; Hosseinzadeh, KH. (2010). Structural model of psychological contract, organizational justice, ethical leadership, LMX and organizational support. Quarterly novelties in industrial /Organizational Psychology, 2 (7): 32-21.

[24] Hatch, J. A. (2002). Doing qualitative research in education settings. Stat university of New York at Albany.

[25] Keefe, L. (2003). How to Overcome organizational Indifference. Women in Business, $55,27-29$.

[26] Keefe, L. (2003). Research Design: Qualitative and Mixed Methods Approaches. Thousand Oaks, CA: Sage.

[27] Leander, P, N. (2009). Kosing the will: Automatic Reactions to the Indifference Perceived in Others. Unpublished master's thesis, DukeUniversity.

[28] Hoy,Vin.K, Miskel, Sisil. J. (2007).Theory, research and practice in management. (Translation by Mir Mohammad Abbaszadeh). Urmia University of Urmia.

[29] Isakhani, A.; Fani, A. A.; Danaei Fard, H. (2013). Explain the antecedents of work engagement by using hybrid research projects. Management of Change Journal, 5 (10): 24-1.

[30] Jalali, M. R.(2014). The relationship between work culture and productivity performance. Monthly Management Engineering, 7 (58)

[31] Jahanian, R., Ghodsi, S.(2014). The relationship between health and organizational justice and professional development of staff in educational organizations. Journal of New Approaches in Educational Management, 5 (3): 114-97.

[32] Karimi, M. Rajayipour, S., Hovida, R. (2010). The relationship between dimensions of organizational climate and ethical behavior among employees of Isfahan University of Medical Sciences. Leadership and Educational Administration Quarterly, 4 (1): 83-102.

[33] Latifian, M.; Tolabi, Z.,Latifian, B.; (2013). The relationship between organizational commitment and organizational indifference with Mellat Bank staff of Ilam province. Management Challenges and Solutions Conference, Shiraz.

[34] Marshall,c.,Ross man, G.B. (1999).Designing qualitative research (3 editions). Thousand Oaks, CA: Sage.

[35] Masterson, S. (2002). Articledown model of organizational relating employees and reactions to Fairness. Journal of Applied Psychology

[36] Mirhosseini Zavareh, S.M. (1995). Organizational Indifference. Journal of Cooperative Economics, 53: 68 
[37] Moayedi, Z. (2013). Analyzing the impact of job characteristics on person-organization fit and organizational indifference (Case Study: Isfahan Province Gas Company). Master thesis, University of Economics and Administrative Sciences.

[38] Moeedfar, S.,Zahani ,G.(2015). Evaluation job dissatisfaction and social factors affecting it. Iranian Journal of Sociology, 6 (1).150 -135.

[39] Moghimi, S. M.(2007). Organization and Management- Research Approaches. Tehran:Termeh

[40] Mohammadpour, A.(2013). Anti-method qualitative research method. Tehran: sociologies.

[41] Mohammadi, B. (2014). Principles of qualitative research methods (Anselm Strauss, Corbin, Juliet). Tehran: Institute for Humanities and Cultural Studies

[42] Morhead, G.,Griffin, R. (2006). Organizational behavior (G. Memarzadeh \& S.M. Alvani).Tehran: Morvarid.

[43] Maxwell, J. A. (1996). Qualitative research design: an interactive approach. Thousand oaks, CA: sage.

[44] Nair, N.,Vohra. N. (2010).An explotation of factors predicting work alienation of knowledge workers, Journal of management history, 48(4), 600-615.

[45] Rezaeian, A. (2001). Management of Organizational Behavior. Tehran: SAMT

[46] Rezaeian, A. (2014). Waiting for justice and righteousness in organization. Tehran: SAMT

[47] Raouf, J.(2013). A Comparative Study of entrepreneurial and work culture based on the wievs of Mazandaran University lecturers and multi-median lecturers of Malaysia. Monthly journal of Labor and Society, 169: 29-23.

[48] Roy. Yong. Joo Chua,Sheena. S. Lyenger, (2005). Empowerment through choice? A critical analysis of the effects of choice in organizations. research in organizational behaviors, 27, 43-49.

[49] Sargazi, H.,Mohammadyari, A.(2014). The relationship between social capital and organizational culture in higher education institutions in Golestan province. Journal of Social Welfare. 14 (166): 155-135.

[50] Seyed Javadin, S. R., Rayej, H., aghamiri, S. A., Yazdani, H. (2009). Marketing for improving behavior of citizenship organization and service quality. Journal of Management Project Science in Iran, 66, 67-97. ( in Persian)

[51] Shahmansouri, A.,Sokutarani, M.(2015). The impact of transformational leadership style on employee self-efficacy. Journal of Management Development and Evolution, 21: 48-43.

[52] Tavasoli, Gh.,Ghadimi, M. (2001). Phenomenon of Work Alienation in organizational structure of Iran. Human science research center of Shahid Beheshti University, 30, p 58.

[53] Yazdani, H. R; Hamidizadeh, A; Kameli, A.(2015). The effect of leadership style and organizational climate on the role of knowledge management regarding organizational structure and social interaction. Journal of Information Technology Management, 7 (1): 216-199.

\section{Article history:}

- $\quad$ Received 25 March 2016

- $\quad$ Accepted 15 May 2016 